\title{
The Impact of Brand, Product Quality and Price on Sales Volume of Samana Mart Stores
}

\author{
I Ketut Suardika ${ }^{1 *}$, Mertyani Sari Dewi²
}

1,2 Sekolah Tinggi Ilmu Ekonomi Satya Dharma, Indonesia

\section{ART ICLE IN F O}

Article history:

Received March 24, 202

Revised April 03, 2021

Accepted May 01, 202

Available online May 25, 2021

Keywords:

Brand, Product Quality, Price, Sales Volume.

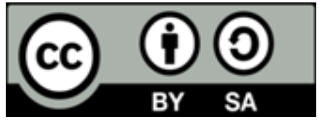

This is an open access article under the CC BY-SA license.

Copyright (C) 2021 by Author. Published by Universitas Pendidikan Ganesha.

\begin{abstract}
A B S T R A C T
Sales volume is the final result achieved by the company from product sales made by the sales department. Sales volume is calculated based on the assumed target with the realization achieved. Sales volume does not separate in cash or credit, but is calculated as a whole from the total achieved. So if the sales volume increases and distribution costs decrease, the company's profit achievement level increases. On the other hand, if the sales volume decreases, the company's profit will decrease. This study aims to determine the effect of brand, product quality and price on sales volume. This research was conducted at the Samana Mart Store. Data collection techniques using a questionnaire, with a sampling technique to 94 consumers. Data analysis used research instrument test, classical assumption test, multiple linear regression test, determination test and significance test with $\mathrm{t}$ test. The results show that the brand has a significant effect on sales volume where the more famous the brand at the Samana Mart Store, the higher the sales volume. The results of the second study, product quality has a significant effect on sales volume, the better the quality of the products owned by the Samana Mart Store, the higher the sales volume. Furthermore, the final result, price has a significant effect on volume, so it can be said that the higher the price, the more competitive the prices offered by Samana Mart Stores, the higher the sales volume.
\end{abstract}

\section{INTRODUCTION}

In order to be able to survive in the midst of competitive competition like today, the company must be able to analyze the existing market share (Machfoedz, 2013; Usmara, 2008). Marketers must look further into the various factors that influence buyers and develop an understanding of how consumers make purchasing decisions (Kotler \& Keller, 2012; Mukiira et al., 2017; Oeyono, 2013). Specifically, marketing must identify the people who make the buying decisions, and the steps in the buying process. Problem recognition, information search, evaluation of alternatives, purchase decisions, behavior after purchase are the stages of consumers deciding to purchase (Anderson et al., 2000; Rachbini, 2018). Increased consumer decisions to purchase a product will also have an impact on increasing sales volume. Sales volume is net sales from the company's profit report (Syaputra, 2020). Net sales are obtained through the sale of all products (product lines) for a certain period of time and sales results achieved from market share, which is potential sales which can consist of groups of buyers for a certain period of time (Ella et al., 2020).

One of the factors that can determine the increase in sales is the brand. A brand is a name or symbol that aims to distinguish and identify the goods or services of one seller or group of sellers who are their competitors (Lenggogeni \& Ferdinand, 2016; Plumeyer et al., 2019). A brand is a name, term, sign, symbol, or design or a combination of these, which aims to identify the goods and services of a group of sellers and to differentiate their products from those of competitors (Dewi \& Suprapti, 2018; Wardani \& Wibowo, 2017). Besides being influenced by the brand, sales volume is also influenced by product quality. To be able to meet the tastes of the community, the company is required to be able to produce goods of value and quality. Products have an important meaning for companies because without products, companies will not be able to do anything from their business. Buyers will buy products if they feel suitable, therefore products must be adjusted to the wishes or needs of buyers so that product marketing is successful. In other words, the manufacture of products is better oriented to market desires or consumer tastes. A product is anything that can be offered to a market for attention, purchase, use, or consumption that can satisfy a want or need (Kotler \& Amstrong, 2015). 
Previous study found that product quality has an effect on sales volume (Mokalu \& Tumbel, 2015). Another study also found that product quality had a significant effect on sales volume (Ummu \& Sumiati, 2016). Apart from being influenced by brand and product quality, sales volume is also influenced by price. Today there are many products on the market and provide an opportunity for consumers to be able to choose good goods according to what consumers are interested in, and of course at an affordable price. Price here is one element of the marketing mix that is very strategic towards increasing sales volume, especially to face competition between companies that produce similar products. The price is the amount of money (plus some goods if possible) needed to get a number of combinations of goods and services (Kukar-Kinney et al., 2012; Sumiati \& Mujanah, 2018). This research was conducted at the Samana Mart Store. Along with increasing consumer demand, now many companies are starting to innovate both in terms of quality and price. In order for the goals set by the company to be achieved properly, the company must design and implement an integrated marketing strategy. Various strategies that have been carried out by the company include maintaining customer loyalty to the brand, maintaining product quality and pricing strategies. Based on the data obtained by researchers at the Samana Mart Store, the sales data of the Samana Mart Store for the last 5 years is shown in Table 1.

Table 1. Sales Tables Samana Mart Store 2016 to 2020

\begin{tabular}{crr}
\hline Year & Total Sales (Rp) & Percentage (\%) \\
\hline 2016 & $1,125,570,000$ & -9.96 \\
2017 & $1,013,446,000$ & -0.88 \\
2018 & $1,004,522,100$ & -1.39 \\
2019 & $990,578,000$ & 3.12 \\
2020 & $1,021,450,000$ & -9.11 \\
Total & $5,155,566,100$ & $\mathbf{- 2 . 2 8}$ \\
\hline Average & $\mathbf{1 , 0 3 1 , 1 1 3 , 2 2 0}$ & \\
\hline
\end{tabular}

Based on the data in Table 1, it can be explained that the sales level of Samana Mart Stores for the last 5 years, namely from 2016-2020 has fluctuated or fluctuated. Average sales for the last 5 years have decreased by an average of $2.28 \%$ each year. Many factors cause a decline in sales, including competitors offering the same product at a lower price with the same quality. In addition, the decline in sales was also due to consumer tastes, substitutes and the image of the company. Sales volume is the final result achieved by the company from product sales made by the sales department. Sales volume is calculated based on the assumed target with the realization achieved. Sales volume does not separate in cash or credit, but is calculated as a whole from the total achieved. So if the sales volume increases and distribution costs decrease, the company's profit achievement level increases. On the other hand, if the sales volume decreases, the company's profit will decrease. This study aims to determine the effect of brand, product quality and price on sales volume.

\section{METHODS}

This research was an explain research that proves the causal relationship between brand, product quality, and price as independent variables and sales volume as the dependent variable. The research framework of this study is presented in Figure 1. The method used in this research was quantitative data (Ferdinand, 2006). In obtained primary data, the author used a questionnaire as a basis for obtaining answers from respondents. This research was conducted at the Samana Mart Store. This research was using purposive sampling technique where the data is examined using measurements by considering individual choices by deliberately selecting respondents, where the population or respondents selected are respondents who did not believe and can provided the necessary information.

The data collection technique used a questionnaire, with a sampling technique to 94 consumers. In this research, questionnaire was using as the data collecting method. The questionnaire was created using a Likert scale. The Likert scale was a scale that used several questions to measure a behavior and answered from respondents (Ghozali, 2018). On the Likert scale, the measurement used was five points of choice; (5) strongly agree, (4) agree, (3) neutral, (2) disagree, and (1) strongly disagree. To verified the proposed hypothesis, validity and reliability were tested to determine the accuracy of the questionnaire. Then the classical assumption test was carried out using SPSS 18. The classical assumption test includes the normality test, to measure the dependent variable and the independent variable on a data that is normally distributed or not. Furthermore, multi collinearity test to see no symptoms of multi collinearity symptoms. Then the heteroscedasticity test was to determine the variant discomfort in a regression 


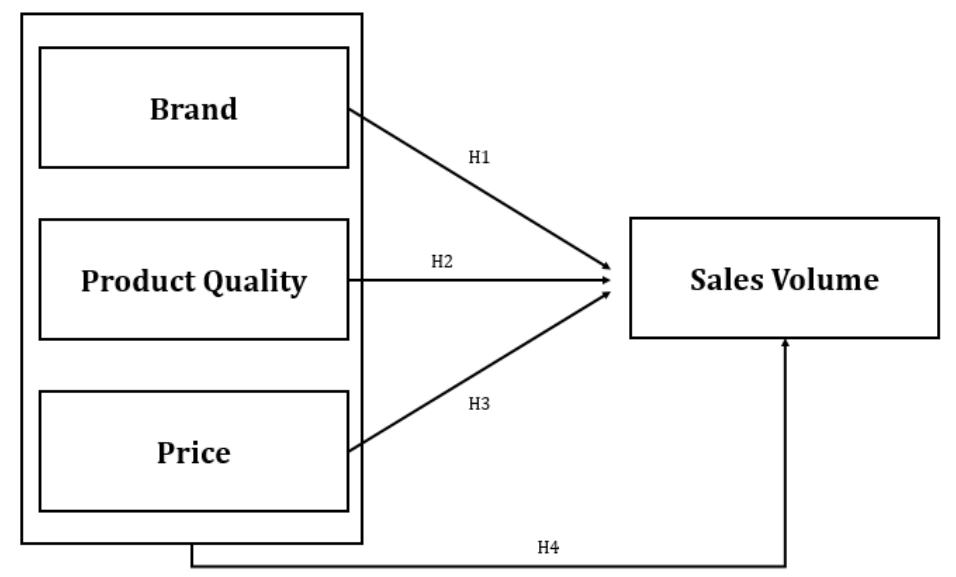

Figure 1. Research Framework

\section{RESULTS AND DISCUSSIONS}

\section{Results}

Multiple Linear Regression Results

Multiple linear regression analysis is used to determine the influence of brand, product quality, and price on sales volume is presented in Table 2 .

Table 2. Multiple Regression Analysis Results

\begin{tabular}{llll}
\hline \multirow{2}{*}{ Model } & \multicolumn{2}{l}{ Unstandardized Coefficients } & \multicolumn{1}{c}{$\begin{array}{l}\text { Standardized } \\
\text { Coefficients }\end{array}$} \\
\cline { 2 - 3 } & $\boldsymbol{B}$ & Std. Error & Beta \\
\hline (Constant) & -0.496 & 0.782 & - \\
Brand & 0.802 & 0.110 & 0.481 \\
Product Quality & 0.328 & 0.114 & 0.202 \\
Price & 0.551 & 0.115 & 0.321 \\
\hline
\end{tabular}

Based on the results which presented in Table 2, the multiple linear regression equation can be prepared as:

$$
Y=-0.496+0.802 X 1+0.328 X 2+0.551 X 3
$$

A constant value of -0.496 illustrates that if the brand, product quality, and price are equal to 0 , the sales volume at the Samana Mart Store is -0.496 units. The regression coefficient of the brand variable is 0.802 , which means that every change or increase of 1 (one) unit brand, the sales volume at Samana Martakan Stores increases by 0.802 , and vice versa, if the brand is reduced (one) unit, the sales volume at Samana Mart will decrease. These changes indicate a positive influence between brands on the volume at Samana Mart Stores. The regression coefficient of the product quality variable of 0.328 means that every change or increase of 1 (one) unit of product quality, the sales volume at Samana Martakan Store increases by 0.328 , and vice versa, if the product quality is reduced (one) unit, then the sales volume at Samana Mart's shop is also going downhill. These changes indicate a positive influence between product quality on sales volume at Samana Mart Stores.

The price variable regression coefficient of 0.551 means that every change or increase of 1 (one) unit price, then the sales volume at Samana Martakan Stores increases by 0.551, and vice versa, if the price policy is reduced (one) unit, then the sales volume at Samana Stores Mart will also decrease. These changes indicate a positive influence between price on sales volume at Samana Mart Stores. This analysis is used to determine the evenness of the relationship between the variables of brand, product quality and price on sales volume. The magnitude of the correlation coffecients (R) can be seen from the magnitude of the $\mathrm{R}$ value of 0.941 . The value of $\mathrm{R}=0.941$ has a positive sign, meaning that the relationship is positive or unidirectional. Furthermore, based on the criteria for the low strength of the relationship according to (Sugiyono, 2013: 183), the correlation coffecients value is 0.941 above, which is between 0.80 to 1,000 , which means that the correlation is very high. This means that simultaneously the independent variable 
brand, product quality and price, has a very high positive relationship with the dependent variable sales volume.

\section{T-Test Results}

Significant value for brand variable is $0.000<0.05$. This means that partially the brand has a real influence on sales volume at Samana Mart Stores. Thus, the first hypothesis proposed in this research is that brand has a positive effect on sales volume received or its validity. (2) The significant value for the product quality variable is $0.005<0.05$. This means that partially the product quality has a significant effect on sales volume at Samana Mart Stores. Thus, the second hypothesis proposed in this research is that product quality has a positive effect on sales volume received or its validity tested. (3) The amount of significant value for the price variable is $0.000<0.05$. This means that partially the price has a significant effect on sales volume at Samana Mart Stores. Thus, the third hypothesis proposed in this research is that price has a positive effect on sales volume received or its validity is tested.

\section{Discussion}

The acceptance of the first hypothesis which states that there is a positive influence between brands on sales volume means that the more famous the brand at Toko Putri Singaraja, the higher the sales volume. The results of this study are in line with the opinion that states a very important factor in influencing sales volume is the brand which aims to see whether market opportunities can provide maximum profit (Chrisandi, 2014; Ella et al., 2020; Fristiana et al., 2012). The results of research found that there is a strong influence between brands and sales volume. Likewise, brands have a significant influence on sales volume (Mokalu \& Tumbel, 2015). The acceptance of the second hypothesis which states that there is a positive influence between product quality and sales volume means that the better the quality of the products owned by Putri Singaraja, the higher the sales volume. The results of this study are in line with the opinion that the factors that affect sales volume include the quality of the product itself (Mokalu \& Tumbel, 2015; Sumiati \& Mujanah, 2018; Sunarto, 2015). The better the quality of the product, the sale of an item or service will increase.The acceptance of the third hypothesis which states that there is a positive influence between price on sales volume means that the higher the price, the more competitive the prices offered by Putri Singaraja Shop are, the higher the sales volume. The results of this study are in line with the opinion which states that the factors that affect sales volume, one of which is the price of products or services (Anderson et al., 2000; Mokalu \& Tumbel, 2015; Saputri et al., 2018; Sigit, 2016). Product quality has an effect on sales volume.

In order to be able to survive in the midst of competitive competition like today, the company must be able to analyze the existing market share (Machfoedz, 2013; Usmara, 2008). Marketers must look further into the various factors that influence buyers and develop an understanding of how consumers make purchasing decisions (Kotler \& Keller, 2012; Mukiira et al., 2017; Oeyono, 2013). Specifically, marketing must identify the people who make the buying decisions, and the steps in the buying process. Problem recognition, information search, evaluation of alternatives, purchase decisions, behavior after purchase are the stages of consumers deciding to purchase (Anderson et al., 2000; Rachbini, 2018). Increased consumer decisions to purchase a product will also have an impact on increasing sales volume. Sales volume is net sales from the company's profit report (Syaputra, 2020). Net sales are obtained through the sale of all products (product lines) for a certain period of time and sales results achieved from market share, which is potential sales which can consist of groups of buyers for a certain period of time (Ella et al., 2020).

One of the factors that can determine the increase in sales is the brand. A brand is a name or symbol that aims to distinguish and identify the goods or services of one seller or group of sellers who are their competitors (Lenggogeni \& Ferdinand, 2016; Plumeyer et al., 2019). A brand is a name, term, sign, symbol, or design or a combination of these, which aims to identify the goods and services of a group of sellers and to differentiate their products from those of competitors (Dewi \& Suprapti, 2018; Wardani \& Wibowo, 2017). Besides being influenced by the brand, sales volume is also influenced by product quality. To be able to meet the tastes of the community, the company is required to be able to produce goods of value and quality. Products have an important meaning for companies because without products, companies will not be able to do anything from their business. Buyers will buy products if they feel suitable, therefore products must be adjusted to the wishes or needs of buyers so that product marketing is successful. In other words, the manufacture of products is better oriented to market desires or consumer tastes. A product is anything that can be offered to a market for attention, purchase, use, or consumption that can satisfy a want or need (Kotler \& Amstrong, 2015). 


\section{CONCLUSION}

Based on the results of the analysis and discussion of the data that have been described in the previous chapter, it can be concluded that for the first direct test the results partially the brand has a real influence on sales volume at the Samana Mart Store. Thus the hypothesis which states that there is a positive influence between brands on sales volume is proven true. The second test, the results state that partially product quality has a significant effect on sales volume at Samana Mart Stores. Thus the hypothesis which states that there is a positive influence between product quality and sales volume is verified. Furthermore, the third test, the results state that partially the price has a significant effect on sales volume at the Samana Mart Store. Thus the hypothesis which states that there is a positive influence between price and sales volume has been proven true.

\section{REFERENCES}

Anderson, J. C., Thomson, B. ., \& Wynstra, F. (2000). Combining value and price to make purchase decisions in business markets. International Journal of Research in Marketing, 17(4), 307-329. https://doi.org/10.1016/S0167-8116(00)00029-X.

Chrisandi, N. P. (2014). Hubungan Citra Merek dan Kualitas Pelanggan dengan Loyalitas Pelanggan Produk $\begin{array}{lll}\text { Apple. } & \text { Calyptra, } & \text { 3(1), }\end{array}$ http://webhosting.ubaya.ac.id/journalubayaac/index.php/jimus/article/view/1515.

Dewi, P. S. A., \& Suprapti, N. W. S. (2018). Membangun Loyalitas Pelanggan Melalui Kepuasan Yang Dipengaruhi Oleh Kualitas Produk, Persepsi Harga dan Citra Merek. Matrik: Jurnal Manajemen, $\begin{array}{lllll}\text { Strategi Bisnis } & \text { Dan }\end{array}$ https://doi.org/10.24843/matrik:jmbk.2018.v12.i02.p01.

Ella, F., Wulandari, T., \& Limbing, L. P. B. (2020). Pengaruh Citra Merek Dan Keputusan Pembelian Terhadap Loyalitas Pelanggan Pada Maskapai Penerbangan Lion Air. Jurnal Hospitality Dan Pariwisata, 6(1), 7-14. https://doi.org/10.30813/.v6i1.2030.

Ferdinand, A. (2006). Metode Penelitian Manajemen. Universitas Diponegoro.

Fristiana, D. A., Prihatini, A. E., \& Listyorini, S. (2012). Pengaruh Citra Merek dan Harga terhadap Keputusan Pembelian pada Ramai Swalayan Peterongan Semarang. JIAB: Jurnal Ilmu Administrasi Bisnis, 1(2), 118-127. https://ejournal3.undip.ac.id/index.php/jiab/article/view/839.

Ghozali, I. (2018). Aplikasi Analisis Multivariate dengan Program IBM SPSS 25 (9th editio). Badan Penerbit Universitas Diponegoro.

Kotler, \& Amstrong. (2015). Marketing an Introducing Prentice Hall twelfht edition. Pearson Education.

Kotler, \& Keller. (2012). Manajemen Pemasaran (12th ed.). Erlangga.

Kukar-Kinney, M., M.Ridgwaya, N., \& B.Monroe, K. (2012). The Role of Price in the Behavior and Purchase Decisions of Compulsive Buyers. Journal of Retailing, 88(1), 63-71. https://doi.org/10.1016/j.jretai.2011.02.004.

Lenggogeni, L., \& Ferdinand, A. T. (2016). Faktor-Faktor Yang Mempengaruhi Keunggulan Bersaing Dalam Upaya Meningkatkan Keputusan Pembelian. Diponegoro Journal of Management, 5(3), 840-851. https://ejournal3.undip.ac.id/index.php/djom/article/view/14673.

Machfoedz, M. (2013). Pengantar Pemasaran Modern. Akademi Manajemen Pemasaran YPKPN.

Mokalu, F. O., \& Tumbel, A. (2015). Pengaruh Kualitas Produk, Harga Dan Distribusi Terhadap Volume Penjualan Roti Jordan CV. Minahasa Mantap Perkasa. Jurnal EMBA: Jurnal Riset Ekonomi, Manajemen, Bisnis Dan Akuntansi, 3(1). https://doi.org/10.35794/emba.v3i1.7085.

Mukiira, E. M., Musau, M. C., \& Munyao, M. J. (2017). Effect of experiential marketing in building brand equity: A case of selected Unilever Tanzania brands. International Journal of Supply Chain Management, 2(1), 1-31. https://www.iprjb.org/journals/index.php/IJSCM/article/view/376.

Oeyono, J. T. (2013). Analisa pengaruh experiential marketing terhadap loyalitas konsumen melalui kepuasan sebagai intervening variabel di tator cafe surabaya town square. Jurnal Strategi Pemasaran, 1(2), 1-9. http://publication.petra.ac.id/index.php/manajemenpemasaran/article/view/959.

Plumeyer, A., Kottemann, P., Böger, D., \& Decker, R. (2019). Measuring brand image: a systematic review, practical guidance, and future research directions. Review of Managerial Science, 13(2), 227-265. https://doi.org/10.1007/s11846-017-0251-2.

Rachbini, W. (2018). The impact of consumer trust, perceived risk, perceived benefit on purchase intention and purchase decision. International Journal of Advanced Research, 6(1), 1036-1044.

Saputri, S. A., Mardani, R. M., \& Wahono, B. (2020). Pengaruh Price Book Value (Pbv), Price Earning Ratio (PER), Return On Asset (ROA) Terhadap Return Saham (Studi Pada Perusahaan Manufaktur Sektor Industri Barang Konsumsi Yang Terdaftar di Bursa Efek Indonesia Tahun 2016- 
2018). Jurnal Ilmiah Riset Manajemen, 9(03). http://www.riset.unisma.ac.id/index.php/jrm/article/view/6152.

Sigit, I. I. A. (2016). Analisis Pengaruh Suasana Toko, Persepsi Harga dan Kualitas Produk Terhadap Minat Beli Dengan Citra Merek Sebagai Variabel Mediasi (Studi Pada Pelanggan Kedai Conel Surakarta). Universitas Negeri Sebelas Maret.

Sumiati, S., \& Mujanah, S. (2018). Persepsi Kualitas Produk, Persepsi Harga dan Promosi Terhadap Keputusan Pembelian Tas Sophie Paris pada Mahasiswa. AMAR (Andalas Management Review), 2(2), 1-10. https://doi.org/10.25077/amar.2.2.1-10.2018.

Sunarto, S. (2015). Pengaruh Kualitas Produk Terhadap Keputusan Pembelian Pada Toko Kerajinan Kulit Kartika Magetan. EQUILIBRIUM: Jurnal Ilmiah Ekonomi Dan Pembelajarannya, 3(2). https: //doi.org/10.25273/equilibrium.v3i2.668.

Syaputra, D. (2020). Pengaruh Harga dalam Meningkatkan Volume Penjualan pada Standard Minimarket Jagakarsa di Jakarta Selatan. Jurnal Manajemen Kompeten, 3(1), 26-38. http://jurnal.stier.ac.id/index.php/mnjm/article/view/141.

Ummu, H., \& Sumiati. (2016). Pengaruh Kualitas Produk dan Harga Terhadap Volume Penjualan Produk Komestik Eardah di Kota Bangkalan Madura. Jurnal Ekonomi \& Bisnis, 1(1). https://doi.org/10.1234/jeb17.v1i01.635.

Usmara, U. (2008). Pemikiran Kreatif Pemasaran. Amara Books.

Wardani, T. A. P., \& Wibowo, S. (2017). The Influence of Rebranding Toward Brand Image of Indosat Ooredoo (Study on Im3 Ooredoo Users in Bandung City). Proceedings of Management, 4(1), 635641.

https://openlibrarypublications.telkomuniversity.ac.id/index.php/management/article/view/46 57. 